\title{
A revision of the millipede genus Riukiupeltis Verhoeff, 1939 (Diplopoda, Polydesmida, Paradoxosomatidae), with comments on the status of related species
}

\author{
Anh D. Nguyen ${ }^{1, \dagger}$, Zoltán Korsós ${ }^{2,3, \ddagger}$ \\ I Institute of Ecology and Biological Resources, No18, Hoangquocviet Road, Caugiay District, Hanoi, Vietnam \\ 2 Department of Zoology, Hungarian Natural History Museum, Baross u. 13, H-1088 Budapest, Hungary 3 Tro- \\ pical Biosphere Research Center, University of the Ryukyus, Senbaru 1, Nishihara, Okinawa 903-0213, Japan \\ † urn:lsid:zoobank.org:author:FCE53D0A-593C-4ACC-800B-E0237DC185F4 \\ $\ddagger$ urn:lsid:zoobank.org:author:60C5576D-D9AB-4DB2-9B5B-053E1E9EFF8E \\ Corresponding author:Anh D. Nguyen (ducanh@ierb.ac.vn, ducanh410@yahoo.com) \\ Academic editor: M. Short | Received 5 September 2011 | Accepted 19 October 2011 | Published 20 December 2011 \\ urn:lsid:zoobank.org:pub:877958A0-6730-4480-9BB7-DDFEEBC89D73 \\ Citation: Nguyen AD, Korsós Z (2011) A revision of the millipede genus Riukiupeltis Verhoeff, 1939 (Diplopoda, \\ Polydesmida, Paradoxosomatidae), with comments on the status of related species. In: Mesibov R, Short M (Eds) \\ Proceedings of the 15th International Congress of Myriapodology, 18-22 July 2011, Brisbane, Australia. ZooKeys 156: \\ 25-40. doi: 10.3897/zookeys.156.2009
}

\begin{abstract}
The East Asian millipede genus Riukiupeltis Verhoeff, 1939 is revised, and is restricted to a single species, $R$. jamashinai Verhoeff, 1939. Examination of the type specimens and freshly collected material from the Ryukyu Archipelago and Vietnam show that both subsequently allocated species, Riukiupeltis uenoi Murakami, 1975, and $R$. falcatus (originally Haplogonosoma falcatum Attems, 1953, reallocated by Jeekel 1968), do not belong to this genus; moreover, they are not even congeneric with each other. According to our morphological observations, including the gonopods, $R$. uenoi is closer to the widespread Chamberlinius hualienensis Wang, 1956, hence we propose the new combination Ch. uenoi (Murakami, 1975), comb. n. Riukiupeltis falcatus, on the other hand, represents a separate, as yet monotypic, genus Simplogonomorpha gen. n., distinct both from Haplogonosoma Brölemann, 1916 sensu Golovatch et al. (1995), and from Verhoeff's original Riukiupeltis. Additionally, Simplogonomorpha falcata (Attems, 1953), comb. $\mathbf{n}$ is re-described here based on fresh material from Vietnam. A key and colour habitus-illustrations to all three species are also provided here.
\end{abstract}

\section{Keywords}

Revision, Riukiupeltis, Paradoxosomatidae, Polydesmida, Vietnam, Japan

Copyright Anh D. Nguyen, Zoltán Korsós. This is an open access article distributed under the terms of the Creative Commons Attribution License 3.0 (CC-BY), which permits unrestricted use, distribution, and reproduction in any medium, provided the original author and source are credited. 


\section{Introduction}

The millipede genus Riukiupeltis was established for a single species $R$. jamashinai by Verhoeff, 1939 from the Ryukyu island Miyako, Japan (Riukiu and Mijako, in German). Jeekel (1968) referred to the genus in his monograph on the distribution of the family Paradoxosomatidae, and placed it in the tribe Tonkinosomatini. Moreover, he also tentatively allocated the species Haplogonosoma falcatum Attems, 1953, described from Xieng Khoang, Laos, to Riukiupeltis. Murakami (1975) described a new species Riukiupeltis uenoi from Sabichi-go Cave, Ishigaki-jima island, the Ryukyus. Therefore, altogether three species have been assigned to Riukiupeltis. The genus belongs to the tribe Chamberlinini, together with Aponedyopus Verhoeff, 1939, Chamberlinius Wang, 1956, Geniculodesmus Chen, Golovatch and Chang, 2008, and Haplogonosoma Brölemann, 1916 (Chen et al. 2011).

Following several discussions on the genus in the past (Jeekel 1968, Hoffman 1973, Murakami 1975, Chen et al. 2011), its status is still dubious, so our purpose here is to provide a revision of the genus based on fresh material and type specimens.

\section{Material and Methods}

Fresh material of Riukiupeltis falcatus (Attems, 1953) and R. uenoi Murakami, 1975 was collected from Bi Doup National Park, Lam Dong province, Vietnam, and Iriomote-jima and Ishigaki-jima islands, the Ryukyu Archipelago, Japan, respectively. The type specimen of $R$. jamashinai was studied as a loan from the Bavarian State Collection of Zoology, Munich, Germany (BSCZ), whereas the holotype of $R$. uenoi was borrowed from the National Museum of Nature and Science, Tokyo (NMNS). Further material is shared between the University Museum (Fujukan) of the University of the Ryukyus, Okinawa (RUMF), the Hungarian Natural History Museum, Budapest (HNHM), and the Institute of Ecology and Biological Resources (IEBR), Hanoi, Vietnam. In addition, new material of $R$. jamashinai was identified in the collection by M. Shimojana, acquired in 1979 on Miyako-jima island.

Line drawings were made by using an Olympus SZX10 (ADN), and a Leica M125 (ZK) stereo microscope with drawing tube attached. SEM images were made by using a Hitachi S4800 scanning electron microscope. Colour photographs were taken by ZK using a Nikon D90 digital camera with macro lens and Leica microscope photo tube attached. The distribution map was generated using the software DIVA-GIS version 7.0. 


\section{Taxonomic account}

\section{Riukiupeltis Verhoeff, 1939}

http://species-id.net/wiki/Riukiupeltis

Riukiupeltis Verhoeff, 1939: Zoologischer Anzeiger 127 (5/6): 121-125 Type species: Riukiupeltis jamashinai Verhoeff, 1939, by monotypy

Riukiupeltis:-Attems 1940: Das Tierreich 70: 546-547.

Riukiupeltis:- Takakuwa 1954: [Diplopoda of Japan]: 51.

Riukiupeltis:- Jeekel 1968: On the classification and geographical distribution of the family Paradoxosomatidae (Diplopoda, Polydesmida), Nederlandse Entomologische Vereiniging: 62,76 . (placed in the tribe Tonkinosomatini)

Diagnosis. Gonofemorite strongly curved, distal part somewhat swollen and membraneous. Postfemoral region demarcated from femorite by obvious cingulum, and bent continuously forming almost a complete circle with femorite. Postfemoral regions consisting of a thick, strong and free solenomere, and an extremely short solenophore (= tibiotarsus).

Type species. Riukiupeltis jamashinai Verhoeff, 1939

Remarks. This genus is relatively close to the genus Chamberlinius Wang, 1956, however, it definitely differs in gonopod conformation: femorite without lamina; solenophore very short, thick, and without any basal processes.

\section{Riukiupeltis jamashinai Verhoeff, 1939}

http://species-id.net/wiki/Riukiupeltis_jamashinai

Figs 1-2, 6A, 7A, 8A, Map 1

Riukiupeltis jamashinai Verhoeff, 1939: Zoologischer Anzeiger, 127 (5/6): 125, fig.8-9. Riukiupeltis jamashinai:- Attems 1940: Das Tierreich 70: 547, fig. 693.

Riukiupeltis jamashinai:- Takakuwa 1954: [Diplopoda of Japan], 52, figs 51-52.

Riukiupeltis jamashinai:- Jeekel 1968: On the classification and geographical distribution

of the family Paradoxosomatidae (Diplopoda, Polydesmida), Nederlandse Entomologische Vereiniging: 76.

Riukiupeltis jamashinai:- Nakamura and Korsós 2010: Acta Arachnologica 59(2): 82.

Material studied. Holotype male, in fragments - only 11 segments in 5 pieces - with segments around gonopods missing, Reg.-Nr. ZSMA20052252, and two slides with gonopods, Reg.-Nr. ZSMA20035204, and legpairs 1-7, Reg.-Nr. ZSMA20035205 (all BSCZ). 


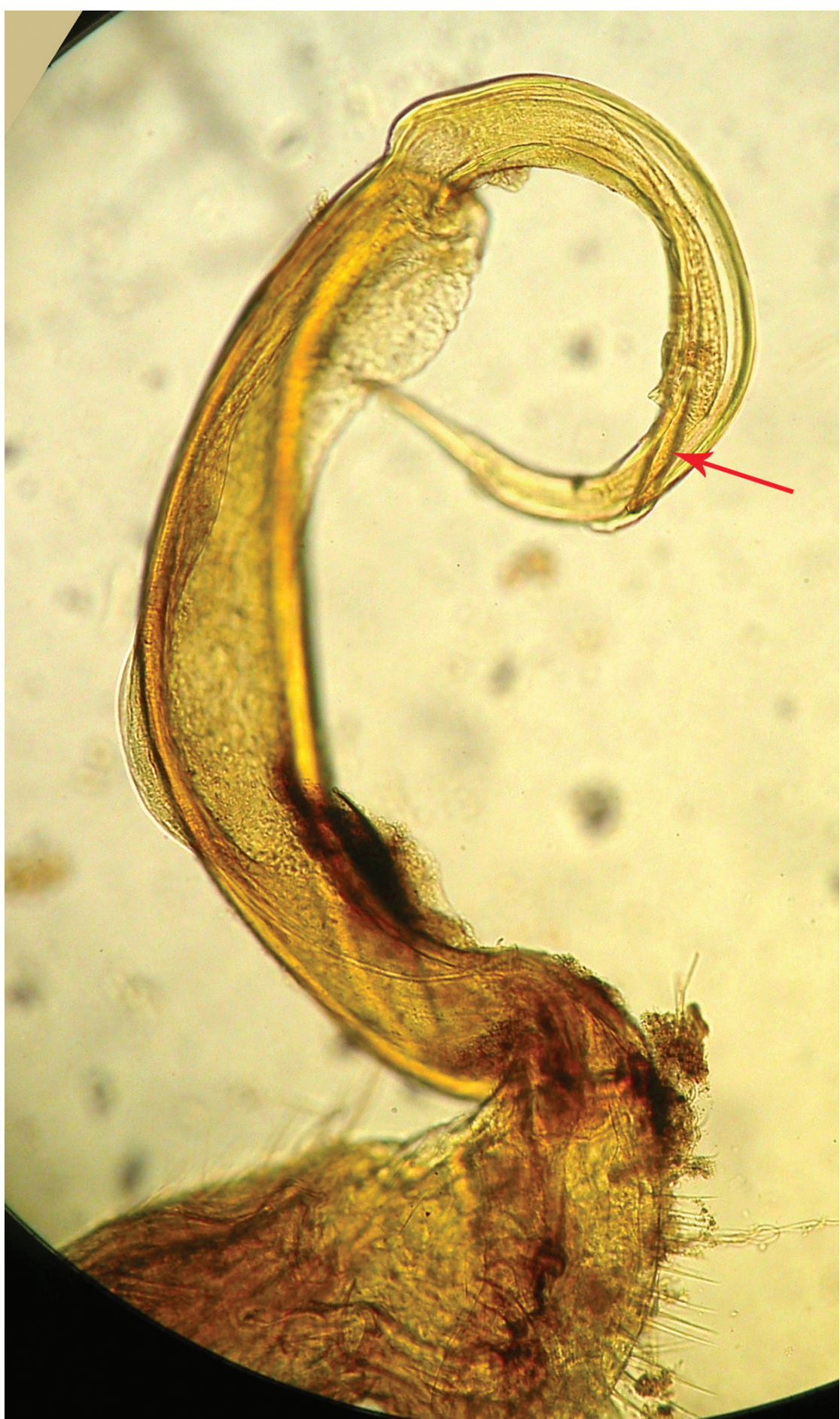

Figure I. Riukiupeltis jamashinai Verhoeff, 1939, right gonopod preparation of holotype (slide Reg.-Nr. ZSMA20035204) (red arrow marks solenophore) 


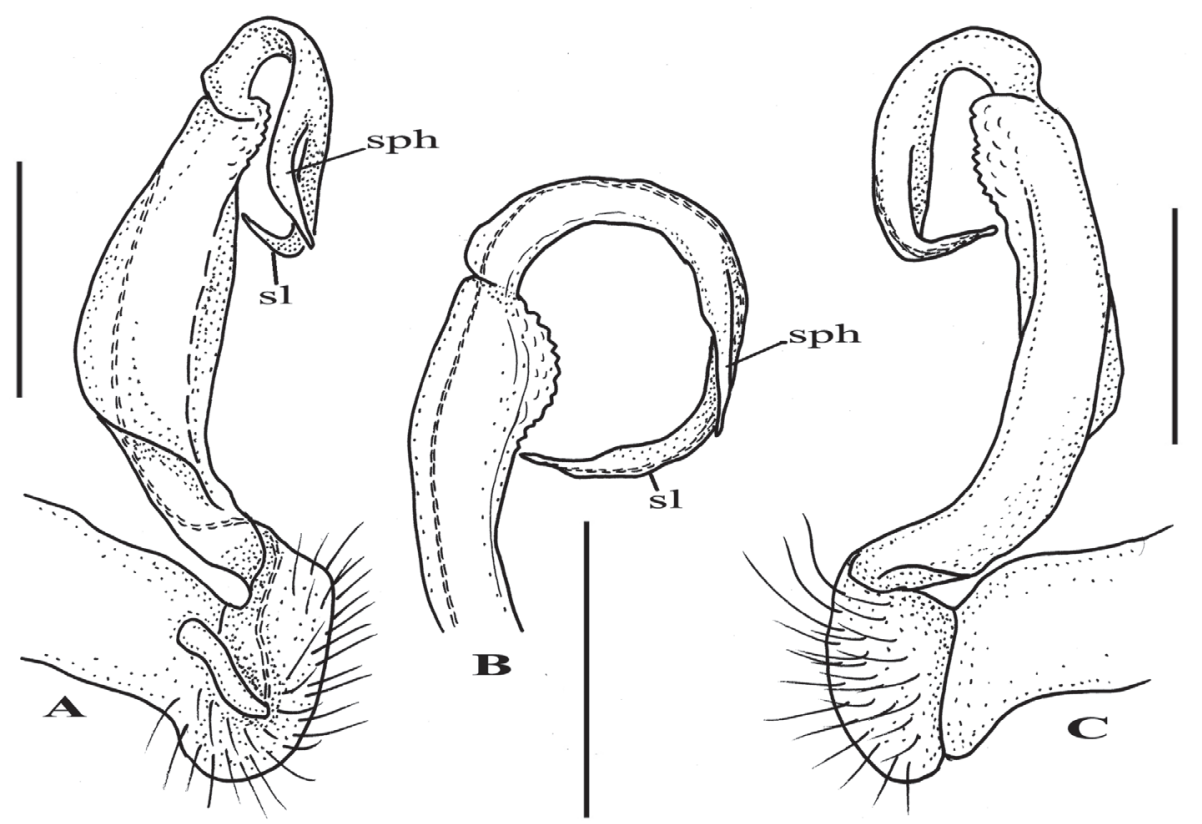

Figure 2. Riukiupeltis jamashinai Verhoeff, 1939, left gonopod of male from Fukumine-no-kara cave, Miyako-jima Island, 25 August 1979, leg. M. Shimojana A mesal view B dorsal view C ventro-lateral view $(s l=$ solenomere, $s p h=$ solenophore or tibiotarsus). Scale bars $=0.5 \mathrm{~mm}$.

New records: 2 males, 2 females, Japan, Ryukyu Archipelago, Miyako-jima Island, Rinko-abu (cave), 21 August 1979; 8 males, 2 females, Japan, Ryukyu Archipelago, Miyako-jima Island, Fukumine-no-kara (cave), 25 August 1979; 1 male, 1 female, 1 juv., 1 fragment, Japan, Ryukyu Archipelago, Miyako-jima Island, Nishibe zuzaga (cave), 26 August 1979, all leg. M. Shimojana (in the collection of M. Shimojana, Okinawa).

Distribution. Japan, Ryukyu Archipelago, Miyako-jima island.

Remarks. Although after the description of R. jamashinai in 1939, Jeekel (1968) and Hoffman (1973) commented that gonopod tibiotarsus is missing in this species, Verhoeff's line drawing clearly shows it as depicted from the slide preparation (Fig. 1). Re-examining the type specimen and the slide of the gonopod, as well as studying newly identified specimens found in Shimojana's collection, we are able to confirm that a gonopod tibiotarsus (=solenophore, $s p \boldsymbol{h}$ in Fig. 2 ) is present, although it is small and closely attached to solenomere (sl in Fig. 2).

Chamberlinius uenoi (Murakami, 1975), comb. n.

http://species-id.net/wiki/Chamberlinius_uenoi

Figs 3, 6C, 7C, 8C, Map 1

Riukiupeltis uenoi Murakami, 1975: Bulletin of the National Science Museum, Tokyo, $\{A\} 1(2):$ 105-107, fig. 9 

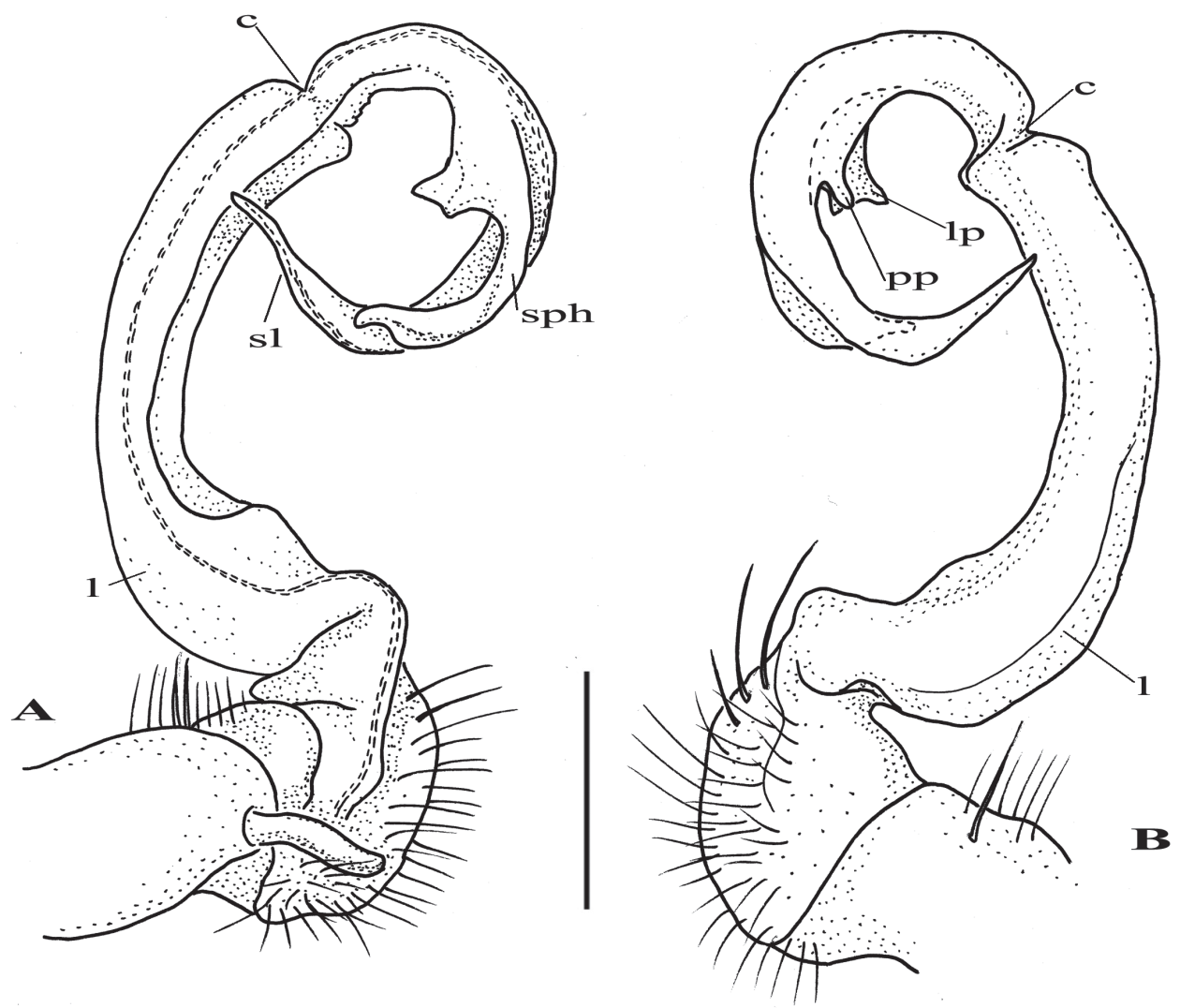

Figure 3. Chamberlinius uenoi (Murakami, 1975) comb. n., left gonopod of male Mt. Banna-dake, Ishigaki-jima Island $\mathbf{A}$ dorso-mesal view $\mathbf{B}$ lateral view. ( $l=$ lamina, $c=$ cingulum, $s l=$ solenomere, $s p h=$ solenophore or tibiotarsal process, $l p=$ laminar process, $p p=$ pointed process)). Scale bar $=0.5 \mathrm{~mm}$.

Riukiupeltis uenoi:- Nakamura and Korsós 2010: Acta Arachnologica 59(2): 82

Material studied. Holotype male, NSMT-My 358, "Japan, Okinawa Pref., Is. Ishigaki-jima, Ibaruma, Sabichi-go Cave, 31 July 1973, coll. by S. Uéno” (NMNS).

New records: 2 males, 1 female, Japan, Ryukyu Archipelago, Yaeyama Island Group, Ishigaki-jima Island, Banna-dake, secondary forest, N24.3859 $-\mathrm{E} 124.1651^{\circ}$, 30 August 2009, leg. Z. Korsós \& Y. Nakamura (RUMF); 1 male, 2 females, Japan, Southern Ryukyus, Yaeyama Group, Iriomote-jima Island, Funaura, around university research station, N24.3929 ${ }^{\circ}, \mathrm{E} 123.7913^{\circ}$, secondary forest, 18 January 2011, leg. Z. Korsós (RUMF); 1 male, 1 female, Japan, Southern Ryukyus, Yaeyama Group, Iriomote-jima Island, Mihara, along Aira river, primary forest, N24.3400', E123.9137 ${ }^{\circ}$, in decaying log, $12 \mathrm{~m}$ a.s.l., 19 January 2011, leg. Z. Korsós (HNHM).

Distribution. Japan, Ryukyu Archipelago, Yaeyama Group, Ishigaki-jima and Iriomote-jima islands. 
Remarks. Murakami (1975) when describing the species commented that the terminal portion of the gonopod is more complicated than that of Riukiupeltis jamashinai Verhoeff, 1939. He also agreed with Verhoeff, 1939 in its configuration, and placed his species in Riukiupeltis. However, the species uenoi, in fact, differs largely from the type species $R$. jamashinai in gonopod conformation.

After studying the type and freshly collected specimens, it became clear that the species uenoi is strongly different from Riukiupeltis jamashinai in its gonofemorite having a long lamina $\boldsymbol{l}$, and a longer solenophore with basal processes $\boldsymbol{p} \boldsymbol{p}$ and $\boldsymbol{l} \boldsymbol{p}$ (Fig 3). We found that this species is more similar to Chamberlinius hualienensis Wang, 1956. Both Ch. hualienensis and Ch. uenoi comb. n. have well-developed paraterga (Figs 7A-B), large, slender and strongly concave gonofemorite, with a lamina at the mesal side ( $\boldsymbol{l}$ in Fig. 3 ). Postfemoral region is demarcated from femorite by obvious cingulum ( $\boldsymbol{c}$ in Fig. 3), and includes a long and large solenomere $(\boldsymbol{s} \boldsymbol{l})$ reaching femur, and a shorter solenophore $(\boldsymbol{s} \boldsymbol{p} \boldsymbol{b})$ with a basal lobe. However, the two species differ from each other in the length of the postfemoral processes, by the shape of the small basal processes on the solenophore, and by live colouration. The dark brown, transversal metatergal bands in Ch. uenoi comb. n. are not divided by a median light brown longitudinal line (Figs 7C, 8C) as in Ch. hualienensis (Figs 7B, 8B). Moreover, Ch. uenoi comb. n. is strictly confined to undisturbed, natural evergreen broadleaf forests, and can only be found deep in decaying dead wood, whereas $C h$. hualienensis has a strong tendency for being synanthropic, and dispersed in large numbers onto many islands (especially in the southern part of Japan) by human activities.

\section{Simplogonomorpha gen. $\mathbf{n}$.}

urn:lsid:zoobank.org:act:878B9422-C9BB-462E-87A5-4A2610BB5B52

http://species-id.net/wiki/Simplogonomorpha

\section{Type species. Haplogonosoma falcatum Attems, 1953, by present designation}

Diagnosis. This genus, Simplogonomorpha gen. n. can be distinguished from other genera within the tribe Chamberlinini Wang, 1956 (as defined by Chen et al. 2011) by the following characters: paraterga modestly developed, gonopod very simple, gonotelopodite tapering and distally curved down as much as forming U-shape or an almost complete circle. Solenomere very simple, thick, but slender, and strongly curved down. Solenophore (= gonopod tibiotarsus) absent.

Etymology. A feminine noun to emphasize the simple gonopod conformation.

Remarks. Jeekel (1968) in his classification of the family Paradoxosomatidae stated that "It appears that in Riukiupeltis the gonopod tiobiotarsus is also completely lost, although Verhoeff was of a different opinion when he described jamashinai". He believed that the gonopod tibiotarsus (= solenophore) was lost in Riukiupeltis, so he transferred Attems's species Haplogonosoma falcatum to this genus.

In fact, the solenophore of $R$. jamashinai still exists, although short, and somewhat hidden next to the solenomere, whereas solenophore of Simplogonomorpha gen. n. is totally missing. A comparison of genera in the tribe Chamberlinini is provided in Table 1. 


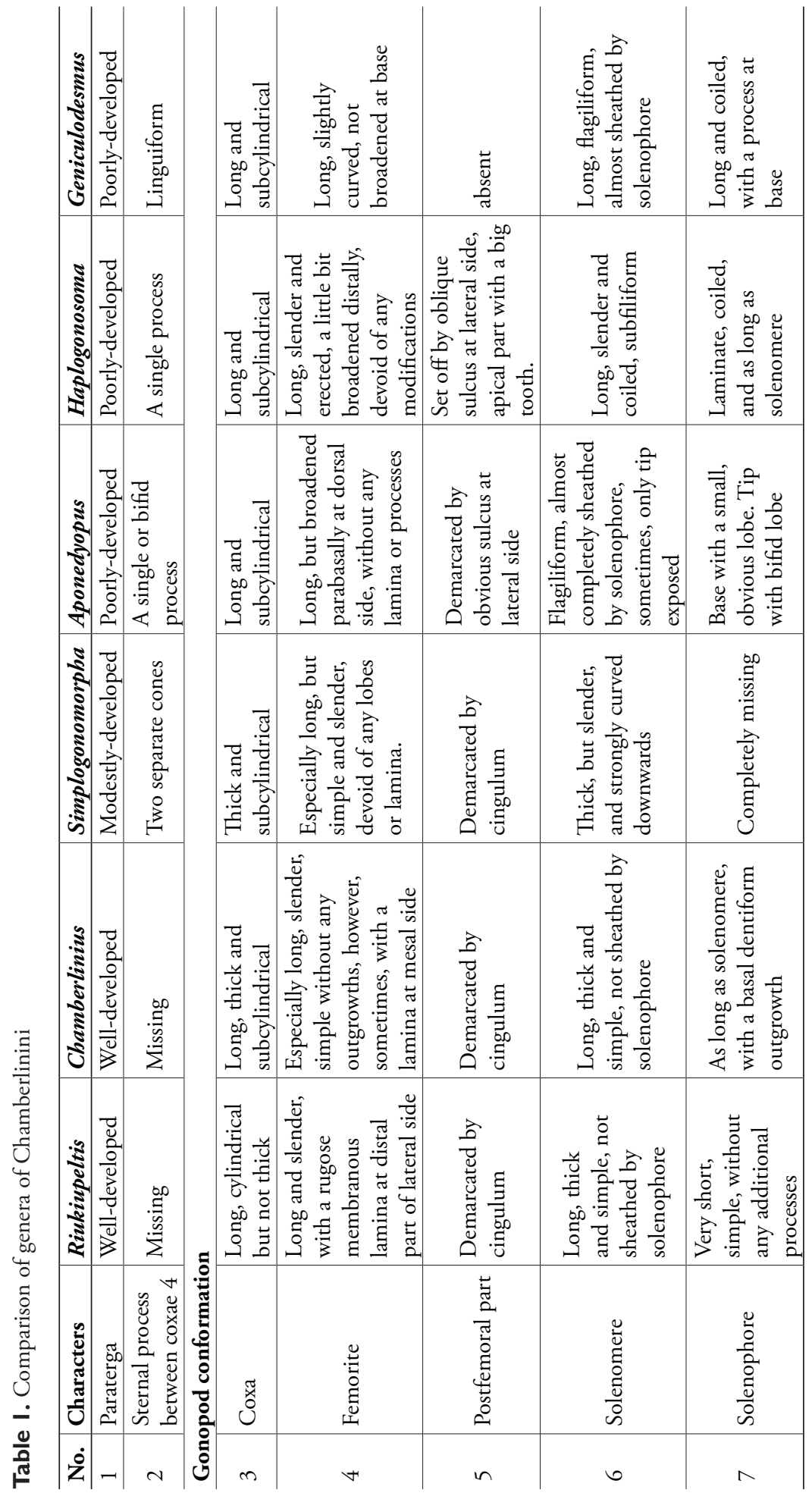




\section{Simplogonomorpha falcata (Attems, 1953), comb. n.}

http://species-id.net/Simplogonomorpha_falcata

Figs 4-5, 7D, Map. 1

Haplogonosoma falcatum Attems, 1953: Mémoires du Muséum National d'Histoire Naturelle, Paris \{N. S., Sér. A, Zool.\}, 5(3): 177, figs 81-82.

Riukiupeltis falcatus:- Jeekel 1968: On the classification and geographical distribution of the family Paradoxosomatidae (Diplopoda, Polydesmida), Nederlandse Entomologische Vereiniging: 62.

Material studied. 3 males, 2 females, (IEBR-166), Vietnam, Lam Dong prov., Bi Doup-Nui Ba National Park, corn field, 1400m a.s.l., pitfall traps, 2-9 April 2008, leg. Anh. D. Nguyen; 1 male, 1 female, 1 juvenile, (IEBR-167), same locality, grasslands, 1400m a.s.l., pitfall traps, 2-9 April 2008, leg. Anh. D. Nguyen; 1 female, (IEBR-168), same locality, bushes near stream, 1400m a.s.l., pitfall traps, 25 April 2008, leg. Anh. D. Nguyen; 4 males, 2 females, (IEBR-169), same locality, evergreen forest, $1800 \mathrm{~m}$ a.s.l., 25 March-23 April 2008, leg. Anh. D. Nguyen;1 male (IEBR-125), Vietnam, Khanh Hoa Prov., Hon Ba Mts., 1300-1500m a.s.l., primary forest, 15-24 April 2006, leg. Anh. D. Nguyen; 1 male, 1 female, (HNHM), same data as sample IEBR-125.

Description. Head: yellowish-brown to blackish brown, a slightly paler toward labrum. Epicranial suture distinct, obviously deep.

Antennae: short and stout, yellowish-brown to blackish brown. Length of antennomere 2 subequal to that of antennomere 3, 4 or 5 . Antennomere 6 shorter and claviform.

Body: yellowish-brown to blackish brown on terga, paler on paraterga and pleura. Body parallel-sided on somites 5-17, thereafter gradually tapering.

Surface of metaterga general fine in posterior part, but with small oblique or longitudinal rugulose in anteriormost part. Stricture dividing pro- and metazona deep, obvious and beaded. Prozona surface shagreened with fine microgranulation.

Transverse sulcus on metaterga starting from somite 5 and more evident on subsequent somites. Metaterga with a row of $2+2$ setae in pre-sulcus part. Axial line vague.

Paraterga not well-developed, small, look like small keels in poreless segments, but more developed in pore-bearing somites. Ozopore located on lateral side, near tip of angular paraterga of segments $5,7,9-10,12-13$ and 15-19.

Pleura shagreened with fine microgranulation. Pleurosternal carinae rather welldeveloped in anteriormost segments, gradually decreasing posteriorly.

Epiproct truncated and curved down ventrad, with 4 strong setae on tip. Anal valves sub-semicircular with $1+1$ long setae, and a deep emargination inbetween. Hypoproct trapeziform, with $1+1$ setae.

Legs: yellow to yellowish brown, short and stout. Tarsal brushes present until legpair 10 , sparsely until legpair 16 , and completely missing thereafter.

Sterna: normal, sparsely setose, with two large tubercles between coxae 4 .

Male gonopod: very simple, hook-like in dorsal view. Coxa subcylindrical, distoventral part sparsely setose. Prefemoral part usually densely setose, with evident demarca- 

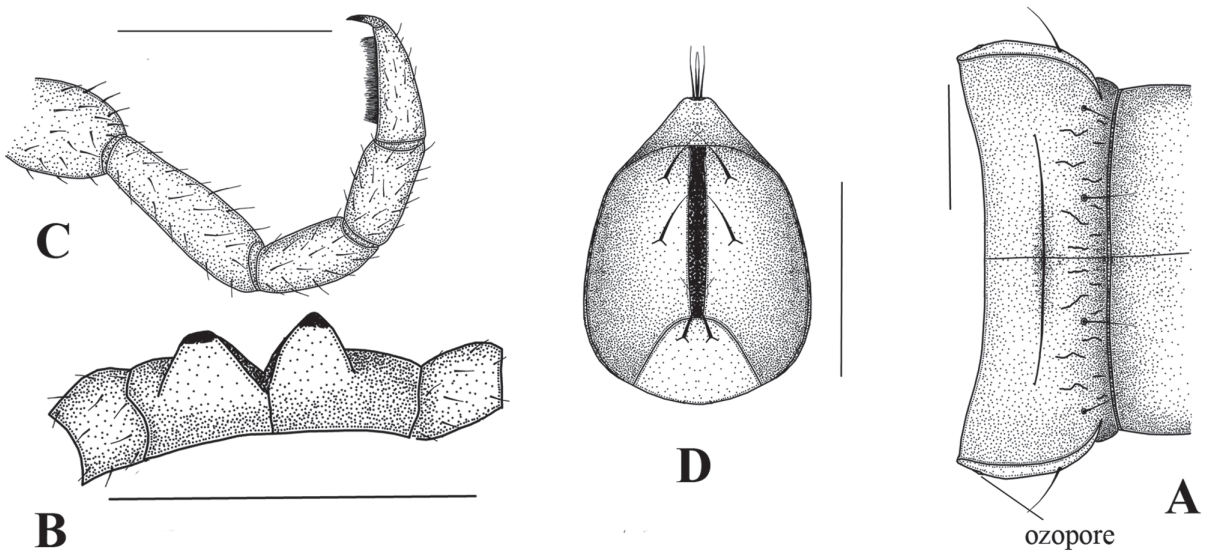

B

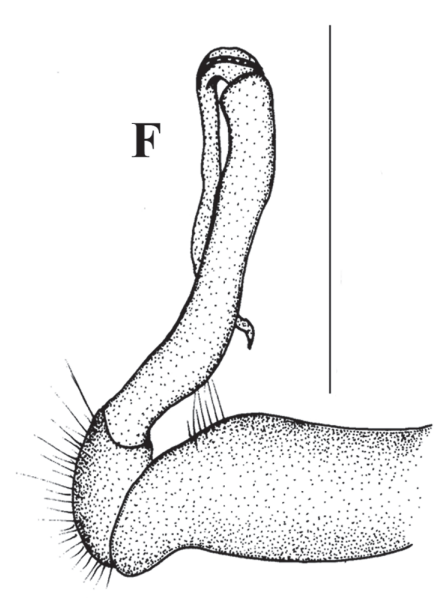

Figure 4. Simplogonomorpha falcata (Attems, 1953) comb. n. from Vietnam, BiDoup National Park A $10^{\text {th }}$ body segment, dorsal view $\mathbf{B}$ sternal processes between $4^{\text {th }}$ coxae, posteriovenral view $\mathbf{C}$ leg 10, lateral view $\mathbf{D}$ telson, ventral view E-G right gonopod $\mathbf{E}$ mesal $\mathbf{F}$ lateral, and $\mathbf{G}$ subdorsal view. Scale bar $=1 \mathrm{~mm}$.

tion from both femorite and coxa. Femorite slender, much longer than coxite and a little curved down distally, separated from postfemoral part by an evident, subtransverse sulcus laterally and mesally. Solenomere simple, strongly curved down, slender, and tapering at tip. Tibiotarsus totally absent.

Prostatic groove runs mesally along femorite, distolaterad, and turns to lateral side, then running mesally, and ending at tip of solenomere.

Distribution. Vietnam, Lam Dong province, Bi Doup-Nui Ba National Park; Khanh Hoa province, Hon Ba Mountain; Laos PDR, Xieng Khoang

Remarks. New material does not much differ from Attems's description. Only minor difference is the presence of two separate cones between coxae 4 instead of only one small conal process in Attems's description. Recently, Chen et al. (2011) also published an illustration of gonopods of Haplogonosoma falcatum collected from the same locality, BiDoup National Park, Vietnam. Our material here fits well with their unevaluated illustration. 


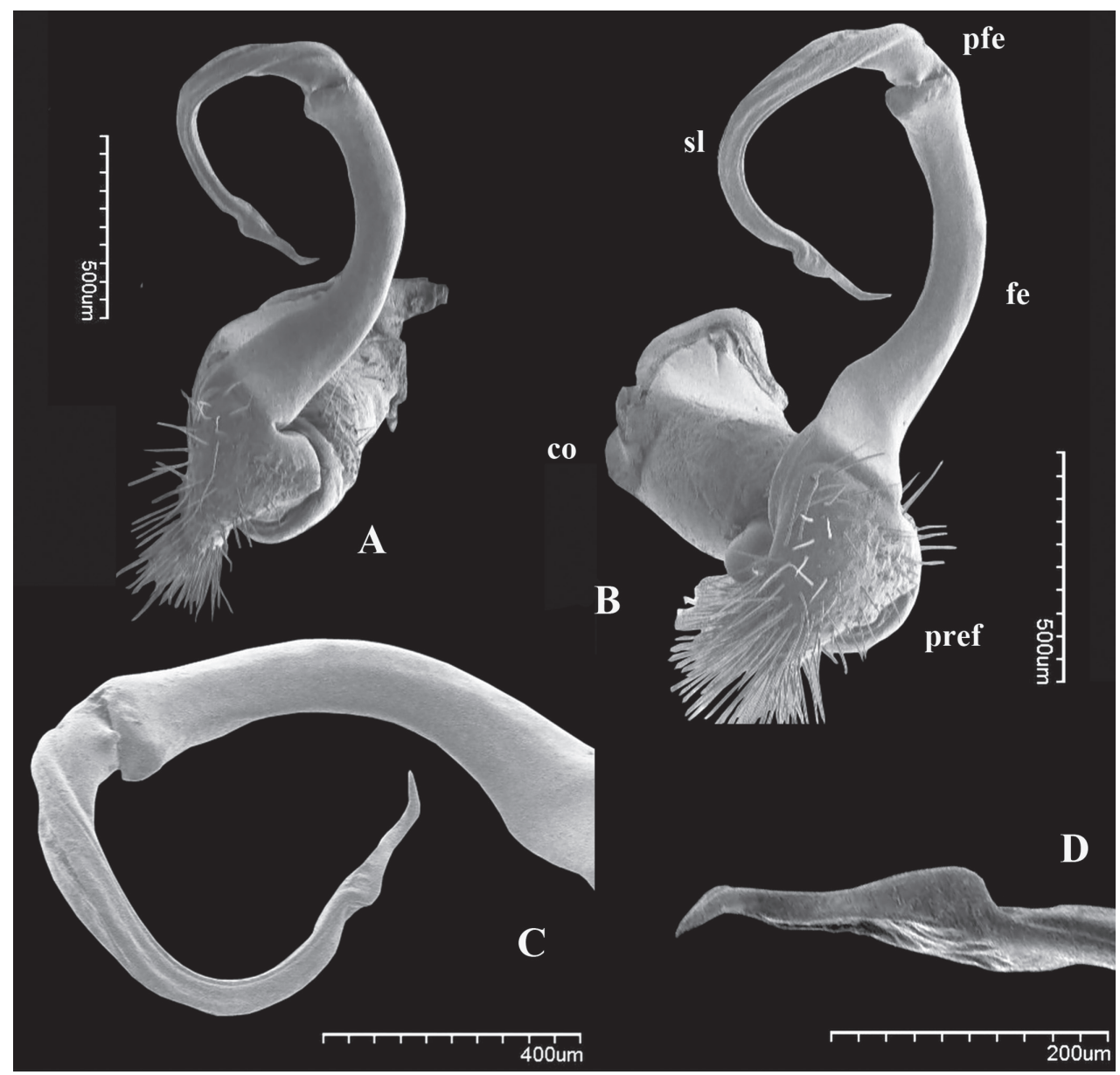

Figure 5. Simplogonomorpha falcata (Attems, 1953) comb. n. from Vietnam, BiDoup National Park, right gonopod: ventral $\mathbf{A}$ and mesoventral view B, C Tip of gonopod, ventral view $\mathbf{D}$.

\section{Key to representatives to all three genera (based on male characters)}

1 Paraterga very weak, body looks almost cylindrical, colour uniformly light brown-yellowish. Gonofemorite very long and slender, without any modifications or processes. Postfemoral region consisting only a simple, strong, long solenomere. Solenophore totally absent (Figs 4-5)....... Simplogonomorpha

- $\quad$ Paraterga well-developed with strong, triangular, posterio-lateral processes. Dorsal metazona colouration divided into dark brown anterior and much lighter posterior half, transversely separated by a deep sulcus.......................2

2 Gonofemorite large, slender and strongly concave, with a lamina on the mesal side. Postfemoral region with a long, large solenomere and a shorter solenophore, the latter basally with two processes, a laminar mesal $(\boldsymbol{l} \boldsymbol{p})$ and a more pointed lateral one $(\boldsymbol{p} \boldsymbol{p})$ (Fig. 3B). 

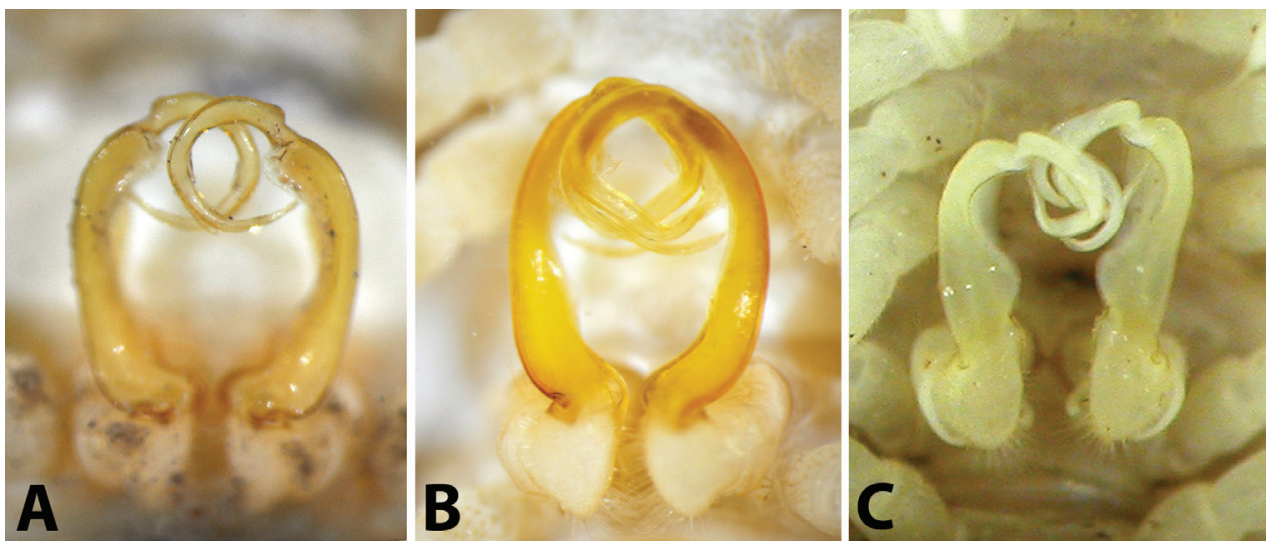

Figure 6. Male gonopods in situ, ventral view: A Riukiupeltis jamashinai (Miyako-jima Island) B Chamberlinius hualienensis (Okinawa-jima Island) C Chamberlinius uenoi comb. n. (Ishigaki-jima Island).
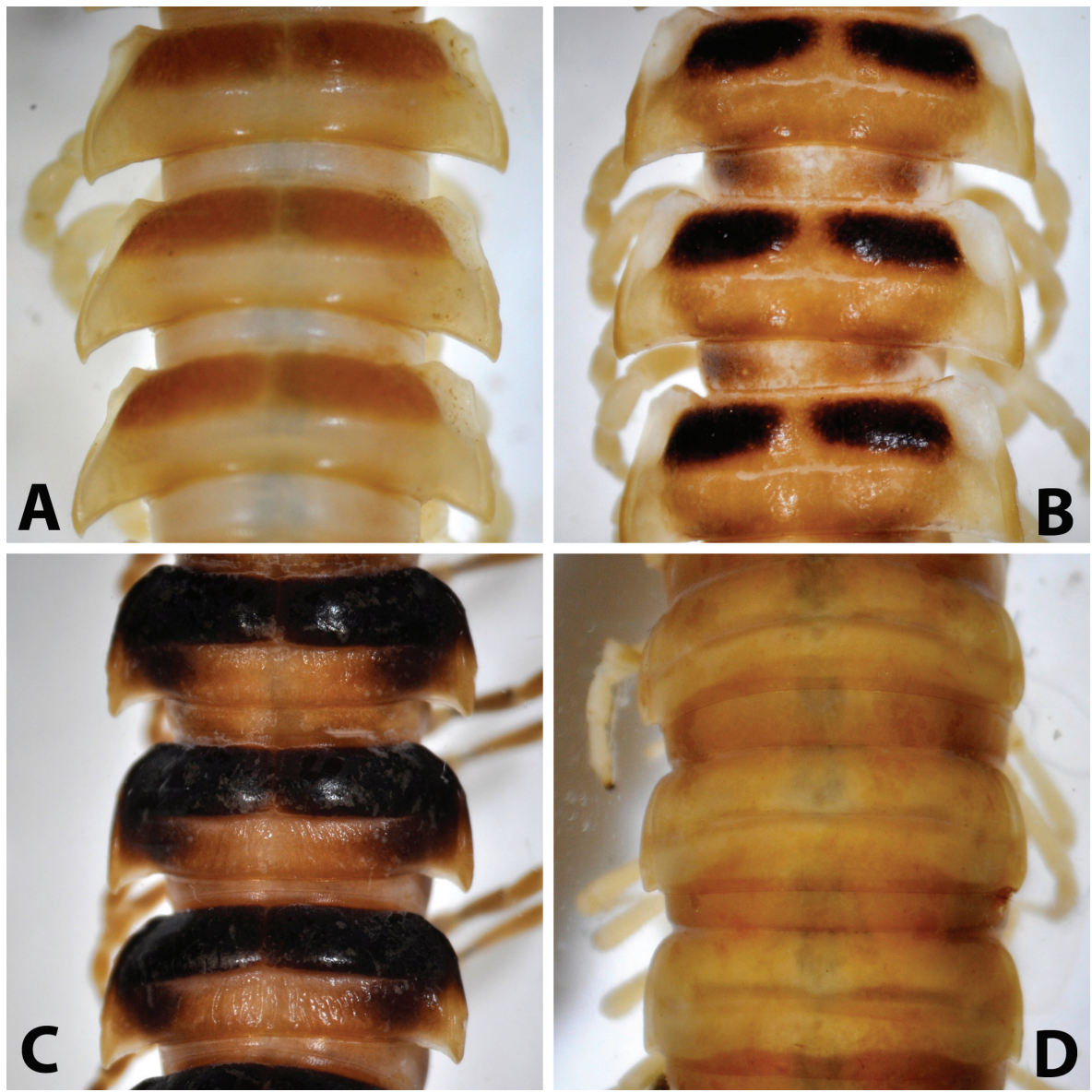

Figure 7. Midbody $\left(11^{\text {th }}-13^{\text {th }}\right)$ segments, dorsal view: A Riukiupeltis jamashinai (Miyako-jima Island) B Chamberlinius hualienensis (Okinawa-jima Island) C Chamberlinius uenoi comb. n. (Ishigaki-jima Island) and D Simplogonomorpha falcata comb. n. (Vietnam, Hon Ba Mts.) 

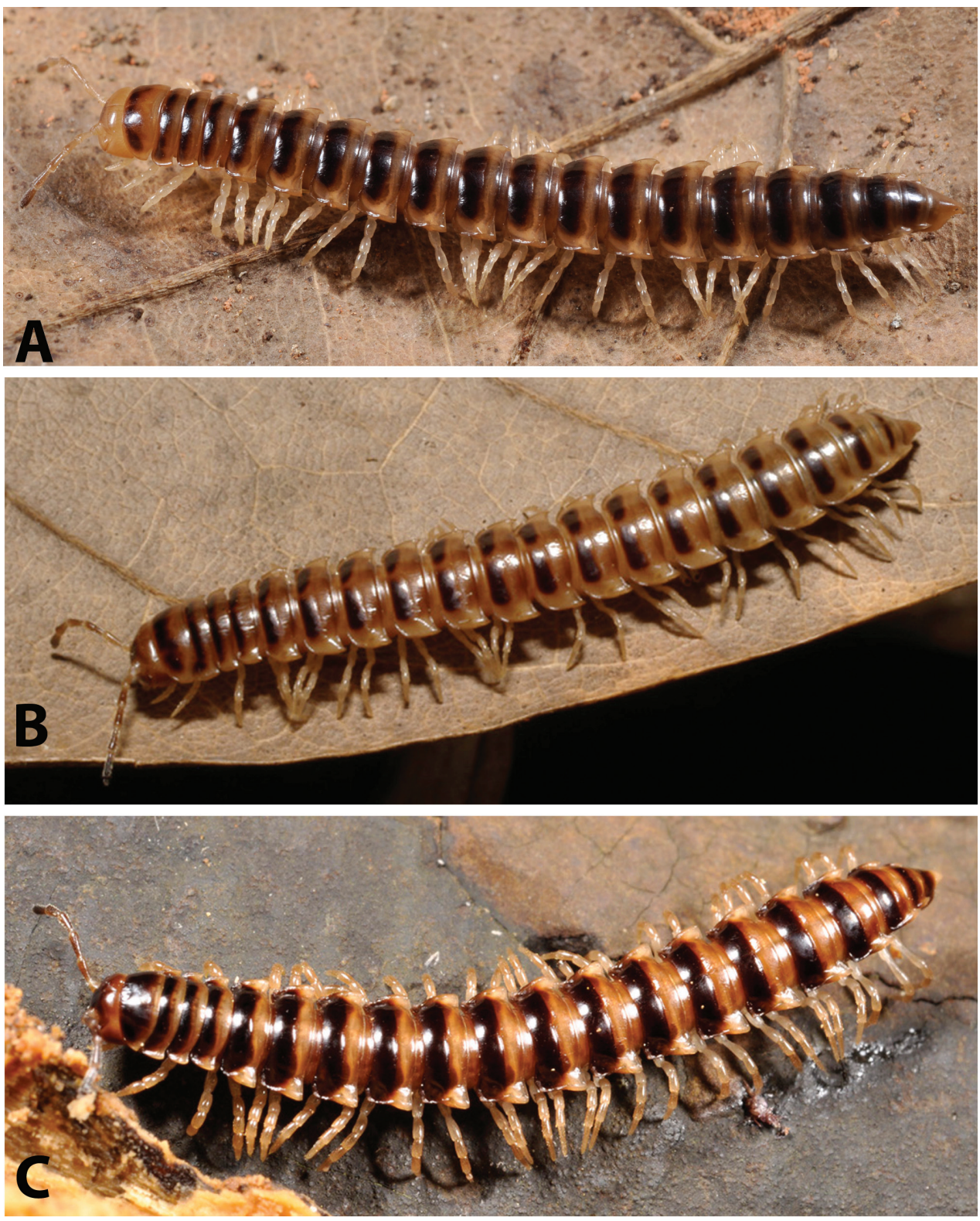

Figure 8. Habitus of millipedes: A Riukiupeltis jamashinai (live from Miyako-jima Island) B Chamberlinius hualienensis (live on Okinawa-jima Island) and C Chamberlinius uenoi comb. n. (live on Iriomotejima Island). 


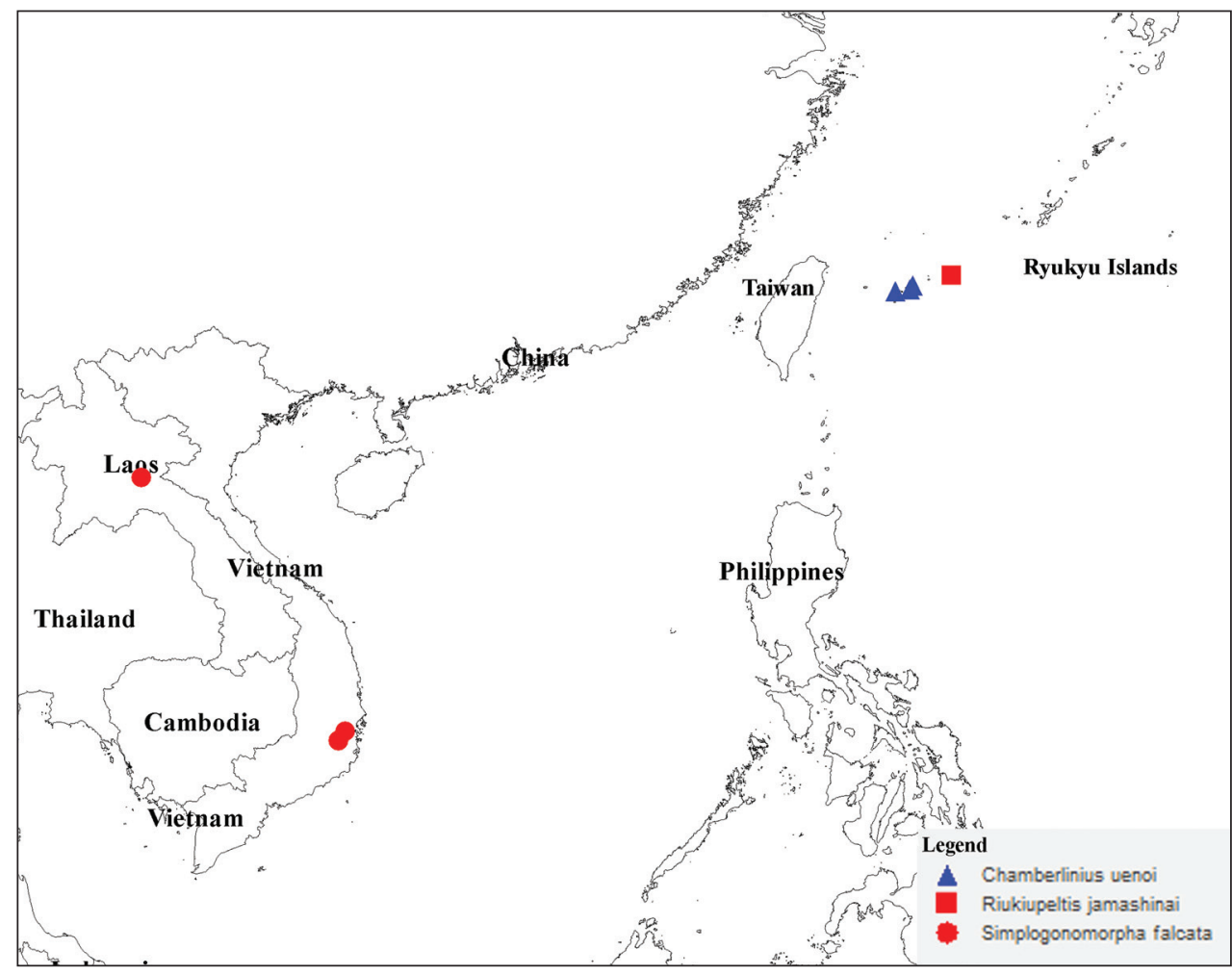

Map I. Distribution of three species Chamberlinius uenoi (Murakami, 1975) comb. n., Riukiupeltis jamashinai Verhoeff, 1939, and Simplogonomorpha falcata (Attems, 1953) comb. n.

- $\quad$ Gonofemorite only slightly curved, with a weak dorsal lamina, distal part swollen and membraneous. Postfemoral region consisting a thick, strong, free solenomere, and a short, somewhat hidden solenophore (Fig. 2) ....... Riukiupeltis

In the key above, Riukiupeltis and Simplogonomorpha are represented by only one species each (jamashinai and falcata, respectively). Chamberlinius, on the other hand, includes at present five species: Ch. hualienensis, Ch. piceofasciatus, Ch. pessior, Ch. sublaevus (all keyed already by Chen et al. 2011), and Ch. uenoi, as added here.

\section{Conclusion}

As a result of our character comparisons, the taxonomic status of the following three species: Riukiupeltis jamashinai Verhoeff, 1939, R. uenoi Murakami, 1975 and R. falcatus (Attems, 1953) has been clarified. Based on significant morphological differences in body shape and gonopod structure, they all belong in three different genera. Riukiupeltis jamashinai having priority is maintained as such, whereas uenoi is transferred to Chamberlinius Wang, 1956, and a new genus, Simplogonomorpha gen. n., is erected to accommodate falcatum. 


\section{Acknowledgements}

We would like to express our deepest thanks to the Vietnamese-Russian Tropical Centre (Vietnam), and the Bi Doup-Nui Ba National Park for supporting the first author during his field expeditions in Vietnam. Special thanks also to the AusAID program of the Australian government for providing financial support through its International Seminar Support Scheme for the first author to participate and present the paper at the $15^{\text {th }}$ International Congress of Myriapodology.

The second author would like to express his sincere gratitude to Prof. H. Ota and M. Toda (Tropical Biosphere Research Center, University of the Ryukyus, Okinawa) for inviting him to study millipedes in the Ryukyus. His study is also supported by the Hungarian Research Fund (OTKA No. 69235). H. Ono (National Museum of Nature and Science, Tokyo) and S. Friedrich (Bavarian State Collection of Zoology, Munich) are deeply acknowledged for arranging the loans of appropriate type material. We also thank M. Shimojana (Urasoe, Okinawa) for letting us study his valuable unidentified material collected in Miyako-jima Island, and Y. Nakamura (Okinawa) for his help in the field and in literature search.

\section{References}

Attems C (1940) Myriapoda 3. Polydesmoidea III. Fam. Polydesmidae, Vanhoeffeniidae, Cryptodesmidae, Oniscodesmidae, Sphaerotrichopidae, Peridontodesmidae, Rhachidesmidae, Macellolophidae, Pandirodesmidae. Das Tierreich 70: 1-577.

Attems C (1953) Myriopoden von Indochina. Expedition von Dr. C. Dawydoff (1938-1939). Mémoires du Muséum National d'Histoire Naturelle, Paris \{N. S., Sér. A, Zool.\} 5(3): 133-230.

Chen CC, Golovatch SI, Chang HW, Chen SH (2011) Revision of the Taiwanese millipede genus Chamberlinius Wang, 1956, with descriptions of two new species and a reclassification of the tribe Chamberlinini (Diplopoda, Polydesmida, Paradoxosomatidae). ZooKeys 98: 1-27. doi: 10.3897/zookeys.98.1183

Hoffman RL (1973) Descriptions and allocations of new or poorly known genera and species of Paradoxosomatidae from south-eastern Asia (Diplopoda: Polydesmida). Journal of Natural History 7: 361-389. doi: 10.1080/00222937300770281

Jeekel CAW (1968) On the classification and geographical distribution of the family Paradoxosomatidae (Diplopoda, Polydesmida). Nederlandse Entomologische Vereiniging 62, 162 pp.

Murakami Y (1975) The cave myriapods of the Ryukyu Islands (I). Bulletin of the National Science Museum, Tokyo, $\{\mathrm{A}\} 1(2): 87-113$.

Nakamura Y, Korsós Z (2010) Distribution and diversity of millipedes of the Ryukyu Archipelago, with the Senkaku and Daito Island Groups: A literature review (Arthropoda: Diplpoda). Acta Arachnologica 59(2): 73-86. doi: 10.2476/asjaa.59.73 
Takakuwa Y (1954) [Diplopoden aus Japan und ihn angrenzenden Gebieten]. Japan Society for the Promotion of Science, Tokyo, 241 pp. [in Japanese with German summary]

Verhoeff KW (1939) Zur Kenntnis ostasiatischer Diplopoden. III. Zoologischer Anzeiger 127(5/6): 113-125.

http://www.diva-gis.org [accessed on March 2011] 